\title{
Communication Between the Mylohyoid and Lingual Nerves: Clinical Implications
}

\author{
Comunicación entre los Nervios Milohioideo y Lingual: Implicancias Clínicas \\ "Valéria Paula Sassoli Fazan; **Omar Andrade Rodrigues Filho \& ${ }^{* * *}$ Fernando Matamala
}

FAZAN, V. P. S.; RODRIGUES FILHO, O. A. \& MATAMALA, F. Communication between the mylohyoid and lingual nerves: Clinical implications. Int. J. Morphol., 25(3):561-564, 2007.

SUMMARY: The mylohyoid muscle plays an important role in chewing, swallowing, respiration and phonation, being the mylohyoid nerve also closely related to these important functions. It has been postulated that the mylohyoid nerve might have a role in the sensory innervation of the chin and the lower incisor teeth while the role of the mylohyoid nerve in the mandibular posterior tooth sensation is still a controversial issue. Although variations in the course of the mylohyoid nerve in relation to the mandible are frequently found on the dissecting room, they have not been satisfactorily described in the anatomical or surgical literature. It is well known that variations on the branching pattern of the mandibular nerve frequently account for the failure to obtain adequate local anesthesia in routine oral and dental procedures and also for the unexpected injury to branches of the nerves during surgery. Also, anatomical variations might be responsible for unexpected and unexplained symptoms after a certain surgical procedure. We describe the presence of a communicating branch between the mylohyoid and lingual nerves in an adult male cadaver, and discuss its clinical/surgical implications as well as its possible role on the sensory innervation of the tongue. The present study reinforces the idea of a communicating branch between the mylohyoid and lingual nerves, indicating that some of the sensory components of the MHN, instead of innervating the teeth or chin skin, might also innervate the tongue and surgeons might be aware of this variation for the correct interpretation of the unexpected findings after oral nerves injury.

KEY WORDS: Mylohyoid nerve; Lingual nerve; Inferior alveolar nerve; Tongue sensation; Teeth sensation.

\section{INTRODUCTION}

The mylohyoid nerve (MHN) is a branch of the inferior alveolar nerve (IAN), which comes $14.7 \mathrm{~mm}$ above the mandibular foramen (Wilson et al., 1984). The nerve then courses downward and anteriorly within the mylohyoid groove on the medial surface of the mandible. The nerve courses anteriorly to parallel the mylohyoid muscle, releasing branches that provide motor innervation to the mylohyoid and anterior belly of the digastric muscles (Clark et al., 1999). The mylohyoid muscle plays an important role in chewing, swallowing, respiration and phonation (Ren \& Mu, 2005), being the MHN also closely related to these important functions. Although the MHN is generally considered to be a motor nerve, it has a sensory component that continues beyond the mylohyoid muscle and anterior belly of digastric muscle, by way of cutaneous branches (Frommer et al., 1972). It has been postulated that the MHN might have a role in the sensory innervation of the chin (Adjei \& Hammersley, 1989; Guyot et al., 2002) and the lower incisor teeth (Frommer et al.; Madeira et al., 1978). The role of the MHN in the mandibular posterior tooth sensation is still a controversial issue (Frommer et al.; Heasman \& Beynon, 1986; Sillanpaa et al., 1988; Clark et al.).

Although variations in the course of the MHN in relation to the mandible are frequently found on the dissecting room, they have not been satisfactorily described in the anatomical or surgical literature (Arensburg \& Nathan, 1979; Kim et al., 2004), and it is well known that this information is

\footnotetext{
* Department of Surgery and Anatomy, School of Medicine of Ribeirão Preto, University of São Paulo, Ribeirão Preto, São Paulo, 14049-900, Brazil.

** Department of Biological Sciences, Federal University of Triângulo Mineiro, Uberaba, Minas Gerais, 38050-050, Brazil.

**** Department of Basic Sciences, School of Medicine, Universidad de La Frontera, Temuco, Chile.

Financial support: CNPq (Conselho Nacional de Desenvolvimento Científico e Tecnológico) grant n 501230/2003-3, FAPESP (Fundação de Amparo a Pesquisa do Estado de São Paulo) grants nº 02/09406-5, 04/01390-8 and 04/09139-2.
} 
of academic interest and also of practical value for oral and maxillofacial surgeons. Also, one of the major complications of a number of oral and maxillofacial surgery procedures is the injury of the lingual nerve (LN). Because of its anatomica location, it may be damaged during third molar extraction, periodontal procedures, mandibular trauma management and excision of neoplastic lesions (Behnia et al., 2000; Kim et al., 2004). Another cause of LN injury may be the needle puncture during local anesthesia or suture (Chossegros et al., 2002; Kim et al.). The major reason for this problem lies in the anatomic variations of the $\mathrm{LN}$ and the inability of the surgeons to know its precise location (Behnia et al.).

It is well known that variations on the branching pattern of the mandibular nerve frequently account for the failure to obtain adequate local anesthesia in routine oral and dental procedures (Jablonski et al.; Krafft \& Hickel, 1994) and also for the unexpected injury to branches of the nerves during surgery (Jablonski et al.; Adjei \& Hammersley; Pogrel \& Thamby, 1999). Also, anatomical variations might be responsible for unexpected and unexplained symptoms after a certain surgical procedure. In this way, the aim of the present study is to describe the presence of a communicating branch between the mylohyoid and lingual nerves, and to discuss its clinical/surgical implications.

\section{CASE REPORT}

An adult, black, male cadaver, aged 55 years, fixed in $10 \%$ formalin solution, was used in this study. The trigeminal nerve of the right side and its branches, from a lateral view (Fig. 1A) were gently dissected and the MHN was exposed in its entire length. In addition, the IAN was carefully dissected free, after the removal of the mandible ramus, to its entrance on the mandibular foramen and, afterwards, part of the mandible bone was removed in order to achieve a better exposure of the $\mathrm{LN}$ trough this lateral approach and also to follow the IAN into its intramandibular course. During the dissection, immediately after the IAN entered the inferior alveolar canal, the MHN appeared thicker than usual (Fig. 1B). Approximately at the level of the digastric muscle intermediate tendon, the MHN gave of a thick branch that joined the LN. Afterwards, the MHN presented its normal course and branching pattern. No anatomical variations were found on the inferior alveolar or the lingual nerves origins. Also, no communicating branches between these two nerves were found. The LN, after receiving this communicating branch from the MHN, also presented normal course and branching pattern.
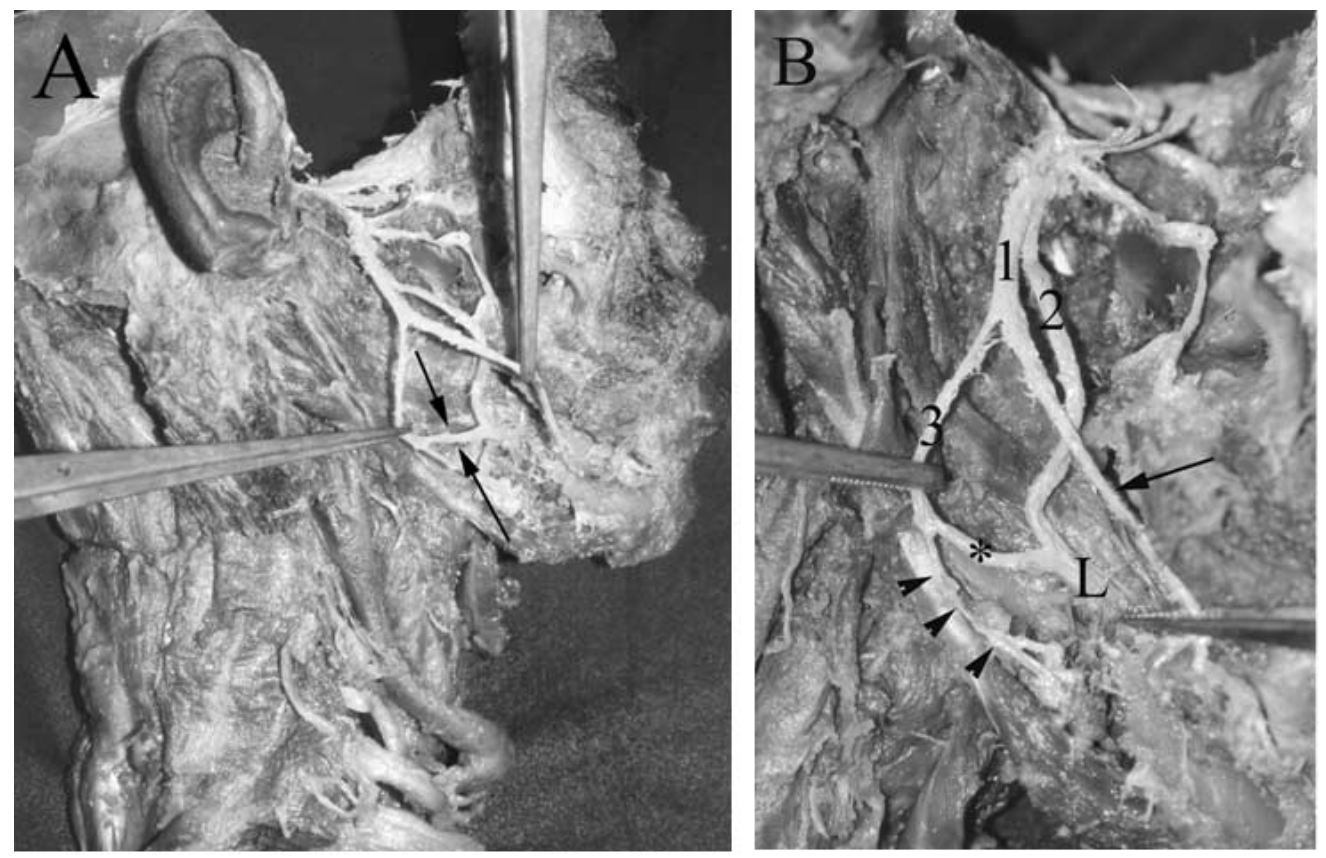

Fig. 1. Lateral view of the right mandibular branches dissection. The communication between the mylohyoid and lingual nerves is shown between arrows in A and is marked with an asterisk in B (in a closer view). Note that the mylohyoid nerve (3) is a thick branch of the inferior alveolar nerve (1), which was dissected free from the alveolar canal (arrow). After giving of the communicating branch $(*)$ to the lingual nerve (2), the mylohyoid nerve follows its normal course (arrowheads). The lingual nerve (L) also continues its normal course after receiving the communicating branch form the mylohyoid nerve. No other communicating branches are found. 


\section{DISCUSSION}

Communicating branches between the IAN and the LN were described in the literature (Racz \& Maros, 1981; Racz et al., 1981; Khaledpour, 1984; Sakamoto \& Akita, 2004) and these communications have been identified as a possible explanation for the inefficiency of mandibular anesthesia (Racz et al.). The existence of communicating branches between the inferior alveolar and lingual nerves is also commonly mentioned in most anatomical text books. Nevertheless, a communicating branch between the mylohyoid and lingual nerves is much less explored in the literature and also not regularly mentioned in the anatomical textbooks.

Racz \& Maros studied 24 human heads and described the existence of a communication between one of the terminal branches of the MHN with the LN, in the lateral sulcus of the tongue. The percentage of appearance of this communication branch was $33.3 \%$ and authors named it as the "mylohyoid or sublingual curl". Later, Bergman et al. (1984) mentioned the existence of this communication in a Catalog of Human Variation. Both authors did not discuss possible clinical implications for this communication. More recently, Kim et al. described the communication between the mylohyoid and lingual nerves in $12.5 \%$ of 32 heads and first mentioned that this communication could provide another route for collateral sensory transmission, being a possible cause of incomplete anesthesia during dental practice. No other reports concerning this communication were found in the literature.

Injury to the $\mathrm{LN}$ is a potential complication of various oral and dental surgeries, and also due to nerve blocks. Nevertheless, is has been pointed out that the injury to the
LN as a result of oral surgery usually results in complete recovery (Reinhart, 1990; Chossegros et al.; Joshi \& Rood, 2002). The communication between the mylohyoid and lingual nerves in this study was found to occur after the $\mathrm{LN}$ passes in close relation to the third molar region. Since this proximity of the $\mathrm{LN}$ and the third molar region is responsible for the relative vulnerable position of this nerve during the third molar surgery (Kiesselbach \& Chamberlain, 1984; Pogrel et al., 1995; Miloro et al., 1997; Behnia et al.), the presence of a nerve communication like the one described in this study would help in the LN function recovery as previously mentioned (Reinhart; Chossegros et al.; Joshi \& Rood), since the MHN would be contributing to the sensory innervation of the tongue.

One of the cardinal factors in minimizing the incidence of nerve damage is the understanding of the local nerves anatomy. The MHN damage has been described as a complication of removal of lower third molar teeth or an excision of the submandibular salivary gland (Adjei \& Hammersley. In the presence of the communicating branch described in this study, if the MHN lesion is too proximal, an impairment of the tongue sensation might occur, without a LN lesion. Also, the high incidence of tongue anesthesia reported by Clark et al. due to the MHN block might not be only due to the close proximity of the LN to the site of the MHN block as reported by the authors, since the communication branch we are describing here is shown in relatively high percentages (Racz \& Maros; Kim et al.). The present study reinforces the idea of a communicating branch between the mylohyoid and lingual nerves, indicating that some of the sensory components of the MHN, instead of innervating the teeth or chin skin, might also innervate the tongue and surgeons might be aware of this variation for the correct interpretation of the unexpected findings after oral nerves injury.

FAZAN, V. P. S.; RODRIGUES FILHO, O.A. \& MATAMALA, F. Comunicación entre los nervios milohioideo y lingual: Implicancias clínicas. Int. J. Morphol., 25(3):561-564, 2007.

RESUMEN: El músculo milohiodeo juega un importante rol en la masticación, alimentación, respiración y fonación, principalmente el nervio milohioideo está íntimamente relacionado en estas importantes funciones. Se ha postulado que el nervio milohioideo pudiese tener un rol en la inervación sensitiva del mentón y de los incisivos inferiores, mientras que el rol del mismo en los dientes posteriores de la mandíbula, es aún una controversia. Aunque variaciones en el curso del nervio milohioideo en relación a la mandíbula son frecuentes de encontrar en la sala de disección, ellas no han sido satisfactoriamente descritas en la literatura anatómica y quirúrgica. Es conocido que variaciones en el patrón de distribución de nervios mandibulares, frecuentemente son consideradas al fracasar en la obtención de una adecuada anestesia en procedimientos orales dentales de rutina y también en la injuria inesperada de los ramos nerviosos durante la cirugía. Además, variaciones anatómicas pueden ser responsables de inesperados e inexplicables síntomas después de ciertos procedimientos quirúrgicos. Describimos la presencia de una ramo comunicante entre los nervios milohioideo y lingual, en un cadáver adulto, de sexo masculino y se discuten sus implicancias clínicas y quirúrgicas y el posible rol en la inervación sensitiva de la lengua. El presente estudio refuerza la idea de un ramo comunicante entre los nervios milohioideo y lingual, indicando algunos de los componentes sensitivos del nervio milohioideo; en cambio, la inervación de los dientes y de la piel del mentón, pudiera inervar la lengua y los cirujanos deberían estar al tanto de esta variación, para una correcta interpretación de los hallazgos inesperados después de una injuria en los nervios.

PALABRAS CLAVE: Nervio milohioideo; Nervio lingual; Nervio alveolar inferior; Sensación lengua; Sensación dientes. 
ACKNOWLEDGEMENTS: The authors are thankful to the late Mr. Arnaldo Geraldino, from the Human Anatomy Discipline, Federal University of Triângulo Mineiro, for his excellent technical support while the study was carried out.

\section{REFERENCES}

Adjei, S. S. \& Hammersley, N. Mylohyoid nerve damage due to excision of the submandibular salivary gland. Br. J. Oral Maxillofac. Surg., 27: 20911, 1989.

Arensburg, B. \& Nathan, H. Anatomical observations on the mylohyoid groove, and the course of the mylohyoid nerve and vessels. J. Oral Surg., 37: 93-6, 1979.

Behnia, H.; Kheradvar, A. \& Shahrokhi, M. An anatomic study of the lingual nerve in the third molar region. J. Oral Maxillofac. Surg., 58: 649-51, 2000.

Bergman, R. A.; Thompson, S. A. \& Afifi, A. K. Catalog of Human Variation. Urban \& Schwarzenberg, Baltimore, 1984.

Chossegros, C.; Guyot, L.; Cheynet, F.; Belloni, D. \& Blanc, J. L. Is lingual nerve protection necessary for lower third molar germectomey? A prospective study of 300 procedures. Int. J. Oral Maxillofac. Surg. 31:620-4, 2002

Clark, S.; Reader, A.; Beck, M.; \& Meyers, W. J. Anesthetic efficacy of the mylohyoid nerve block and combination inferior alveolar nerve block/ mylohyoid nerve block. Oral Surg. Oral Med. Oral Pathol. Oral Radiol. Endod., 87:557-63, 1999.

Frommer, J.; Mele, F. A. \& Monroe, C.W. The possible role of the mylohyoid nerve in mandibular posterior tooth sensation. J. Am. Dent. Assoc. 85:113-7, 1972.

Guyot, L.; Layoun, W.; Richard, O.; Cheynet, F. \& Gola, R. Alteration of chin sensibility due to damage of the cutaneous branch of the mylohyoid nerve during genioplasty. J. Oral Maxillofac. Surg., 60: 1371-3, 2002.

Heasman, P. A. \& Beynon, A. D. G. The role of mylohyoid nerve in mandibular tooth innervation. J. Dent., 14:80-1, 1986.

Jablonski, N.G.; Cheng, C. M.; Cheng, L. C. \& Cheung, H. M. Unusual origins of the buccal and mylohyoid nerves. Oral Surg. Oral Med. Oral Pathol., 60:487-8, 1985.

Joshi, A. \& Rood, J. P. External neurolysis of the lingual nerve. Int. J. Oral Maxillofac. Surg., 31:40-3, 2002.

Khaledpour, V. C. An anatomic variant of the inferior alveolar nerve in man. Anat. Anz., 156: 403-6, 1984.

Kiesselbach, J. E. \& Chamberlain, J.G. Clinical and anatomic observation on the relationship of the lingual nerve to the mandibular third molar region. J. Oral Maxillofac. Surg., 42: 565-7, 1984.

Kim, S.Y.; Hu, K.S.; Chung, I. H.; Lee, E.W. \& Kim, H. J. Topographic anatomy of the lingual nerve and variations in communication pattern of the mandibular nerve branches. Surg. Radiol. Anat., 26:128-35, 2004.
Krafft, T. C. \& Hickel, R. Clinical investigation into the incidence of direct damage to the lingual nerve caused by local anaesthesia. $J$. Craniomaxillofac., Surg. 22:294-6, 1994.

Madeira, M. C.; Percinoto, C.; Silva, M. G. M. Clinical significance of supplementary innervation of the lower incisor teeth: A dissection study of the mylohyoid nerve. Oral Surg., 46: 608-14, 1978.

Miloro, M.; Halkias, L. E.; Slone, H.W. \& Chakeres, D.W. Assesment of the lingual nerve in the third molar region using magnetic resonance imaging. J. Oral Maxillofac. Surg., 55:134-7, 1997.

Pogrel, M. A.; Renaut, A. \& Ammar, A. The relationship of the lingual nerve to the mandibular third molar region: An anatomic study. J. Oral Maxillofac. Surg., 53:1178-81, 1995.

Pogrel, M. A. \& Thanby, S. The etiology of altered sensation in the inferior alveolar, lingual and mental nerves as a result of dental treatment. $J$. Calif. Dent. Assoc., 27:351, 354-8, 1999.

Racz, V. L.; Maros, T. \& Seres-Sturm, L. Anatomical variations of the nervus alveolaris inferior and their importance for the practice. Anat. Anz., 149:239-332, 1981.

Racz, V. L. \& Maros, T. The anatomic variants of the lingual nerve in human. Anat. Anz., 149:64-71, 1981.

Reinhart, T.C. Anatomic variation of the position of the lingual nerve. $J$. Periodontol., 61:305-6, 1990.

Ren, M. \& Mu, L. Intrinsic properties of the adult human mylohyoid muscle: Neural organization, Fiber-type distribution, and myosin heavy chain expression. Dysphagia, 20:182-94, 2005.

Sakamoto, Y. \& Akita, K. Spatial relationships between masticatory muscles and their innervating nerves in man with special reference to the medial pterygoid muscle and its accessory muscle bundle. Surg. Radiol. Anat., 26:122-7, 2004

Sillanpaa, M.; Vuori, V. \& Leihtinen, R. The mylohyoid nerve and mandibular anesthesia. Int. J. Oral Maxillofac. Surg., 17:206-7, 1988.

Wilson, S.; Johns, P. \& Muller, P. M. The inferior alveolar and mylohyoid nerves: An anatomic study and relationship to local anesthesia of the anterior mandibular teeth. J. Am. Dent. Assoc., 108: 350-2, 1984.

\section{Correspondence to:}

Dr. Valéria Paula Sassoli Fazan, M.D., Ph.D.

Assistant Professor

Department of Surgery and Anatomy

School of Medicine of Ribeirão Preto, USP,

Av. Bandeirantes 3900,

CEP 14049-900.

Ribeirão Preto, SP, BRAZIL

E-mail: vpsfazan@fmrp.usp.br or vpsfazan@yahoo.com.br

Received: 09-08-2006

Accepted: 25-06-2007 